\title{
Reconstruction of a distal extremity defect using a temporoparietal fascia flap covered with a split-thickness skin graft harvested from the scalp: a cosmetic consideration in donor site selection
}

\author{
Distal ekstremite defektlerinin temporaoparietal fasya ve \\ skalpten alınan kısmi kalınlıklı deri grefti ile rekonstrüksiyonu: \\ Donör saha seçimine kozmetik bir yaklaşım
}

\author{
Özlenen ÖZKAN, ${ }^{1}$ Ömer ÖZKAN, ${ }^{1}$ Gamze BEKTAȘ, ${ }^{1}$ Samir MARDINI, ${ }^{2}$ Paolo SASSU, ${ }^{2}$ \\ Emanuele CIGNA, ${ }^{2}$ Serdar TÜZÜNER, ${ }^{3}$ Hung-Chi CHEN ${ }^{2}$
}

\section{BACKGROUND}

In reconstructive surgery, the ultimate goal in rebuilding a structure is to provide the most similar substitute from both the functional and structural points of view. At the same time, the reconstructive surgeon should focus on minimizing donor area complications.

\section{METHODS}

In this report, we present our experiences with the reconstruction of distal extremity defects using a free temporoparietal fascia flap in five patients. The flap was subsequently covered with a split-thickness skin graft harvested from the same region of the scalp as the flap donor site.

\section{RESULTS}

By procuring the skin graft from the scalp, the donor sites of both the flap and the skin graft were concealed by hair. The transferred flaps and skin grafts healed uneventfully in all patients without any complications at the donor or recipient site.

\section{CONCLUSION}

We conclude that this combination of harvesting a temporoparietal fascia flap, which has many advantages in reconstructing distal extremity defects, along with a skin graft from the same region as the flap, both hidden by hair, can limit donor site morbidity and achieve optimal reconstructive outcomes.

Key Words: Cosmetic consideration; graft; temporoparietal fascia flap; scalp.

\section{AMAC}

Rekonstrüktif cerrahide asıl amaç, fonksiyonel ve yapısal açılardan en benzer doku ile yeniden yapılanmanın sağlanmasıdır. Ancak rekonstrüktif cerrah aynı zamanda donör alan komplikasyonlarını en aza indirmeye de odaklanmalıdır.

\section{GEREC VE YÖNTEM}

Biz bu çalışmamızda beş hastada distal ekstremite defektlerinde temporoparietal fasya flebi ve deri grefti ile rekonstrüksiyon deneyimlerimizi sunduk. Temporoparietal fasya flebi skalpte aynı bölgeden alınan kısmi kalınlıkta deri grefti ile kapland.

\section{BULGULAR}

Greftin skalpten alınması ile hem flep hem greft donör alanları saçların arkasında gizlenmiş oldu. Transfer edilen flep ve greftler tüm hastalarda herhangi bir donör alan komplikasyonu görülmeden olaysız şekilde iyileşti.

\section{SONUÇ}

Distal ekstremite defektlerinde temporaparietal fasya kullanmanın sayısız avantajına ek olarak bunu aynı alandan alınan kısmi kalınlıkta deri grefti ile kombine etmenin hem skarı saçlar tarafindan gizleyerek donör alan morbiditesini azaltması hem de optimal rekonstrüktif sonuçları sağlaması açısından iyi bir seçenek olduğunu düşünüyoruz.

Anahtar Sözcükler: Kozmetik önem; greft; temporaoparietal fasya flebi; skalp.

\footnotetext{
Departments of ${ }^{1}$ Plastic and Reconstructive Surgery, ${ }^{3}$ Orthopedics and Traumatology, Akdeniz University Faculty of Medicine, Antalya, Turkey; ${ }^{2}$ Department of Plastic and Reconstructive Surgery, E-Da Hospital / I-Shou University, Kaohsiung County, Taiwan.
} 
In any kind of tissue defect, the surgeon must consider several factors when selecting the appropriate method of reconstruction. During the reconstruction of a structure, in an otherwise healthy patient, it is obvious that the ultimate goal is to replace like with like. However, this particular principle cannot be achieved in many clinical situations. Thus, the reconstruction is performed with tissue that is similar yet not identical. The reconstructive surgeon must take into consideration the aesthetic outcome at both the donor site and the recipient site. Prior to the era of reconstructive microsurgery, options for coverage of tissue defects consisted of allowing the wound to heal by secondary intention, skin grafting, as well as local and regional flap coverage, many of which were at times insufficient to meet requirements at the recipient site. The advent of free tissue transfer has provided multiple reconstructive options that have allowed for the preservation and maintenance of the functional, structural and aesthetic status of both the recipient and donor sites.

The choice of soft tissue for coverage of defects of the upper and lower extremities is dependent on the extent and location of the wound. The aim when treating extremity defects, as is the case with other defects in the body, is to preserve function while achieving a sound aesthetic outcome. Although local fasciocutaneous and muscle flaps may be appropriate and adequate for many defects in the extremities, advances in microsurgical techniques have permitted reliable wound closure and a substantial decrease in patient morbidity with low complication rates while allowing a variety of reconstructive flap options in a single stage.

The temporoparietal fascia flap, with its consistent vascular pedicle, is a thin, supple, pliable, and versatile flap that can be used for a variety of complex reconstructive efforts. ${ }^{[1-5]}$ This flap has ample intrinsic blood supply to improve local wound vascularity and allow for excellent wound healing. ${ }^{[1-6]}$ The temporoparietal fascia flap itself is harvested from a region that is inconspicuous, due to its ease of concealment by hair. However, its requirement for skin grafting, in order to complete the reconstruction, necessitates the creation of another donor site for skin grafting.

In this report, we present our experiences with distal foot and hand defects reconstructed using a free temporoparietal fascia flap in five patients. The fascia flap was subsequently covered with a split-thickness skin graft, harvested from the same region of the scalp as the flap. The donor sites for both the flap and the skin graft were prepared simultaneously and were limited to an area that was easily concealed by hair. Structural and aesthetic viewpoints at both the donor site and the reconstructed site were considered and are discussed in this manuscript.

\section{MATERIALS AND METHODS}

From October 2004 through May 2009, five free temporoparietal fascia flaps were used to reconstruct soft tissue defects of the distal foot and hand defects. There were 4 males and 1 female, aged 9-21 years (Table 1). All patients had crush injury due to traumas. The size of the flaps ranged from $10-13 \mathrm{~cm}$ long and 6-8 cm wide.

For practical purposes, the right side of the scalp was selected as the donor area for both a fascia flap and a skin graft. This side of the face and scalp were then prepared and draped in the usual sterile fashion after shaving of the hair. Prior to elevation of the flap, in order to increase the skin tension and the surface area of the skin of the scalp, saline was injected into the subgaleal plane. A split-thickness skin graft, measuring approximately 12/1000th of an inch in thickness, was taken from the temporoparietal region utilizing an air-driven dermatome. A preauricular incision starting at the level of the tragus was made and extended superiorly to the superior temporal line, at which point it was converted to a curved Y-shaped incision. The superficial temporal artery and its two concomitant veins were identified, exposed, and isolated. The dissection of the anterior and posterior scalp flaps was carried out in a subcutaneous plane, deep to the hair follicles. Marking of the fascia flap was made and elevated over the level of the deep temporal fascia (in the plane of the loose areolar tissue). The flap was harvested from cephalad to caudad until the flap was fully mobilized and the pedicle length was adequate. The flap was then transferred to the defect and the superficial temporal artery was anastomosed to the recipient artery, and the concomitant veins of the flap were anastomosed to the concomitant deep recipient vein and/or -if it was reliable- to a superficial vein. The skin graft, which

Table 1. Patient summary

\begin{tabular}{lcclcc}
\hline No & Age $(\mathrm{y})$ & Sex & Cause & Flap size $(\mathrm{cm})$ & Complication \\
\hline $1^{*}$ & 9 & F & Crush injury, right foot & $7 \times 12$ & None \\
2 & 18 & M & Crush injury, right hand & $7 \times 13$ & None \\
3 & 21 & M & Crush injury, left hand & $6 \times 10$ & None \\
$4^{*}$ & 14 & M & Crush injury, right hand & $7 \times 11$ & None \\
5 & 18 & M & Crush injury, left foot & $8 \times 13$ & None \\
\hline
\end{tabular}

M: Male; F: Female. *: Presented cases. 
was harvested from the scalp, was cleaned well and all remnant hair shafts were removed. Holes were made in the graft using a no. 11 blade, and the graft was used to cover the fascia flap. The wound of the donor area was closed primarily, and the donor area of the skin graft was covered with Tegaderm (3M Healthcare, St. Paul).

Patient 1- A nine-year-old girl had a bicycle accident that resulted in a crush injury and loss of soft tissue in the distal part of the right foot (Fig. 1a). The patient was seen at an outlying hospital where primary repair of the lacerations was performed and dressing changes to the dorsal foot wound were instituted. The patient presented to our clinic 20 days later with a soft tissue defect over the dorsum of the foot. The 4th toe and the distal phalanx of the $3 \mathrm{rd}$ and 5 th toes had been amputated. The dorsal foot defect extended from the 2nd to the 5th metatarsal bones. The distal third of the 3rd metatarsal and the proximal phalanx of the 3rd toe as well as the overlying tendons were exposed. There was necrotic skin over the third web space. The remaining soft and hard tissues of the foot, along with its blood supply, appeared to be intact. The dorsalis pedis and posterior tibial arteries were palpable. X-ray examination identified the level of amputation of the
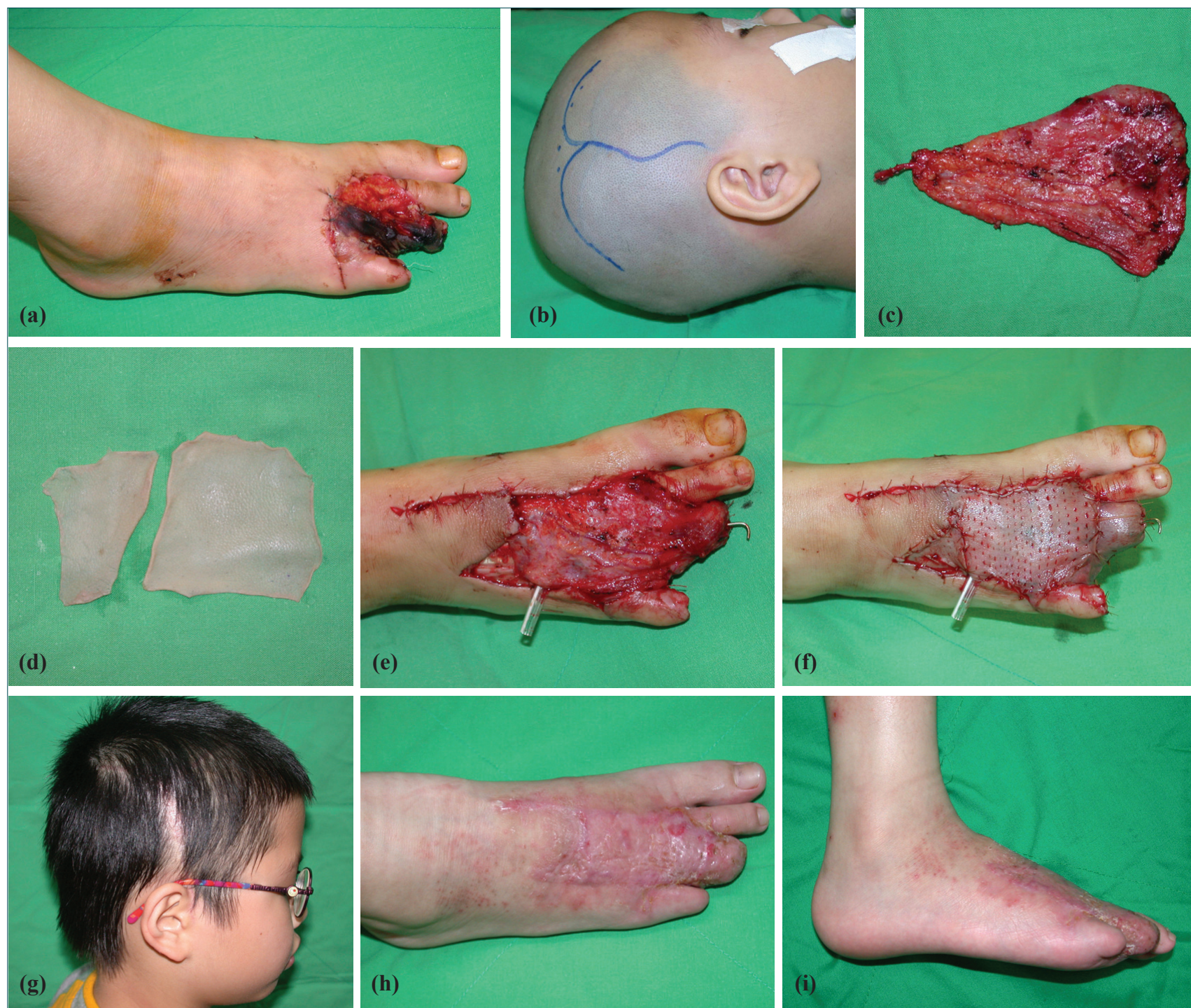

Fig. 1. (a) A crush injury of the foot in a 9-year-old patient. (b) Preoperative preparation for the procedure and marking for the temporoparietal fascia flap. (c) Harvest of the temporoparietal fascia flap based on the superficial temporal vessels. (d) Harvest of a split-thickness skin graft from the scalp. (e) The defect after coverage with the free temporoparietal fascia flap. (f) The surface of the fascia flap was covered with a split-thickness skin graft harvested from the scalp. (g) A postoperative view of the dorsal aspect of the foot at the 4-month follow-up. (h) A postoperative view of the lateral aspect of the foot at the 4-month follow-up. Note the natural contour of the flap and the cosmetic outcome, which was a result of the thinness of the flap. (i) Postoperative view of the donor area.

(Color figures can be viewed in the online issue, which is available at www.tjtes.org). 
4th toe to be at the metatarsophalangeal joint and of the 3rd and 5th toes to be at the distal interphalangeal joints. The remaining bones of the foot were without fractures. The patient underwent surgical debridement of the wound, at which time it was noted that the proximal interphalangeal joint of the 3 rd toe was exposed and dislocated. Because of the strong desire of the family for the preservation of the length of the toes, this was fixed using Kirschner wire. The dorsalis pedis artery along with its concomitant veins and a superficial vein on the dorsum of the foot were prepared as recipient vessels.
The soft tissue defect was closed with a temporoparietal fascia flap measuring 7 x $12 \mathrm{~cm}$ (Figs. 1b, 1c, 1d). The superficial temporal artery was anastomosed to the dorsalis pedis artery, and the concomitant veins of the flap were anastomosed to one dorsalis pedis concomitant vein and to the previously exposed superficial dorsal foot vein (Fig. 1e). The proximal part of the fascia flap was used to resurface the dorsal foot defect, and the distal aspect of the flap was used to cover, circumferentially, the degloved 3rd toe. The vascular pedicle of the flap was covered with a proximally based local skin flap from the dorsum of the foot. The skin graft, which was harvested from the scalp, was
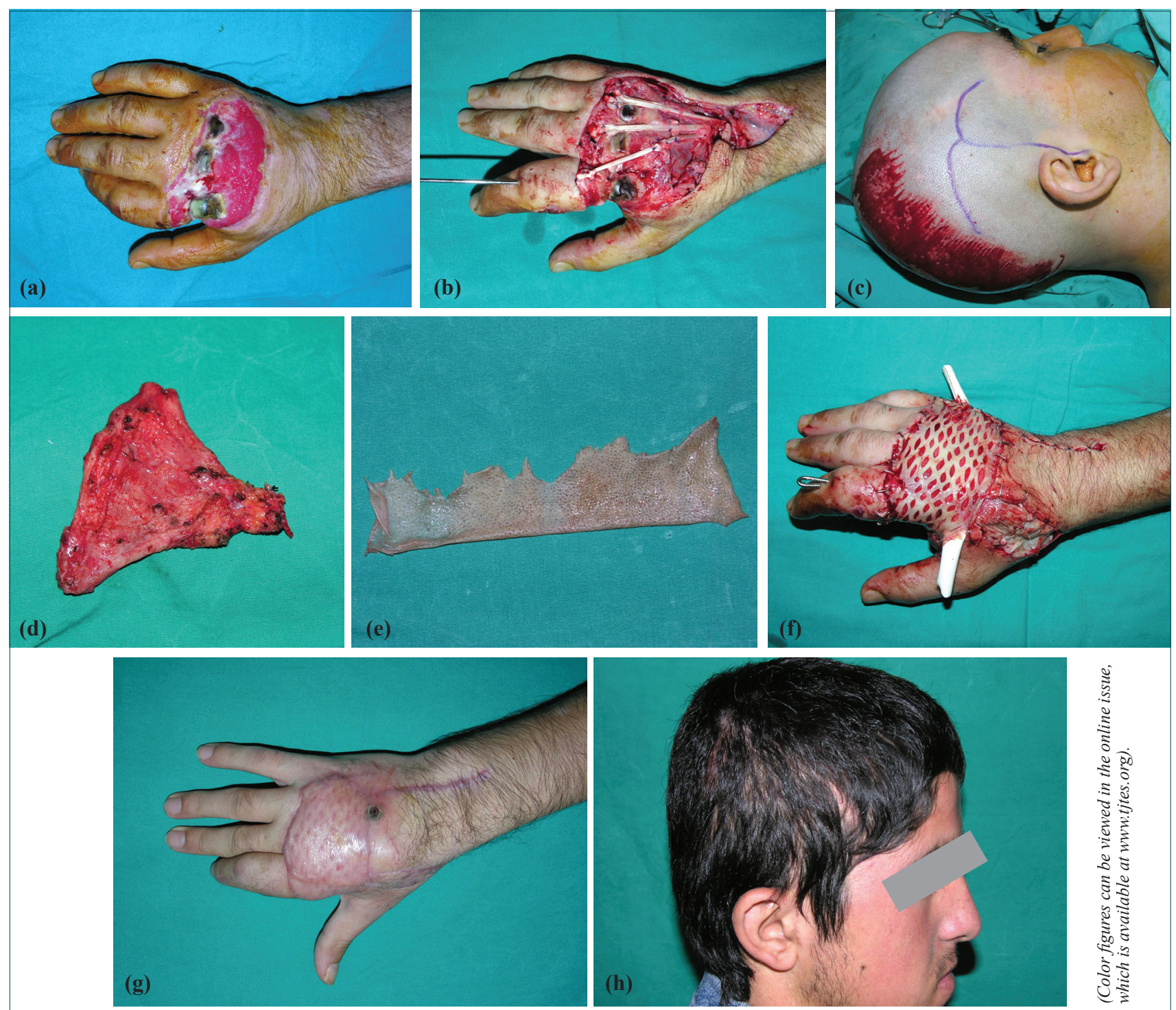

Fig. 2. (a) Extensive soft tissue defect in the dorsal aspect of the right hand in a 14-year-old patient. (b) Intraoperative view after debridement of the wound and repair of the tendon with a tendon graft and fixation of the second metacarpal bone fracture. (c) Intraoperative view after harvesting a skin graft from the scalp and marking for the temporoparietal fascia flap. (d) Harvest of the temporoparietal fascia flap based on the superficial temporal vessels. (e) Harvest of a split-thickness skin graft from the scalp. (f) Immediate postoperative view after coverage with the free temporoparietal fascia flap. The surface of the fascia flap was covered with a split-thickness skin graft harvested from the scalp. (g) A postoperative view at the 3-month follow-up. (h) Postoperative view of the donor area. 
used to cover the fascia flap (Fig. 1f). Postoperative recovery was uneventful, and the flap survived completely. There was complete take of the split-thickness skin graft (Figs. 1g, 1h, 1i). The Kirschner wire was removed three weeks postoperatively. There was no problem with hair growth in the scalp. The thinness of the flap allowed the patient to wear a shoe at four months postoperatively (Fig. 1h).

Patient 2- A 14-year-old male patient was referred to the Plastic Surgery clinic with a crush and avulsion injury to the distal part of the right upper extremity caused by a vehicular accident. Physical examination revealed skin defect and crush injuries in the dorsal aspect of the right hand (Fig. 2a). The circulation of the hand was not affected, and distal pulses were palpable. However, there was severe crush and avulsion injury to the extensor surface of the hand. The second metacarpal bone was exposed with multiple fractures, and the external extensor tendons of the 2 nd and 3 rd fingers were defective. Under X-ray, multiple fractures of the second metacarpal bone were apparent. Wound debridement of the soft tissues was performed, and tendon defects were repaired with tendon grafts. The metacarpal bone was repaired using a Kirschner wire (Fig. 2b). The superficial radial artery along with its concomitant veins and a superficial vein on the dorsum of the foot were prepared as recipient vessels.

The temporoparietal fascia flap measuring $7 \times 11$ $\mathrm{cm}$ and the skin graft were harvested in the same manner (Figs. 2c, 2d, 2e). The flap was then transferred to the defect and the superficial temporal vessels were anastomosed to the superficial radial vessels. The skin graft, which was harvested from the scalp, was used to cover the fascia flap (Fig. 2f). The postoperative recovery was uneventful, and the flap survived completely (Fig. 2g). There was complete take of the splitthickness skin graft. The Kirschner wire was removed six weeks postoperatively. There was no problem with hair growth in the scalp (Fig. 2h).

\section{RESULTS}

No flap required reoperation due to vascular compromise. All flaps survived completely. No secondary corrections, including debulking procedure and scar revision, were necessary. No infections or hematomas were observed. All flap donor sites that were closed directly healed with minimal scar requiring no correction. None of the cases had postoperative alopecia with hair growth problem in the skin graft donor area.

\section{DISCUSSION}

In reconstructive surgery, the surgeon should focus on preserving and maintaining the natural status of the patient by minimizing complications in the flap donor region, while achieving optimal results in the recipient defects. The choice of soft tissue coverage of defects of the lower extremity depends on the extent and location of the wound. While local fasciocutaneous and muscle flaps are sufficient for certain defects of the limbs, they are usually not adequate for coverage of many defects. Advances in microsurgery have provided alternative reconstructive options in which large defects can be reconstructed in one stage using free tissue transfer. At the same time, free tissue transfer allows the preservation of local tissues, thus keeping the functional and cosmetic impairment of an already injured extremity to a minimum.

Fascial flaps possess unique advantages related to their tissue quality. ${ }^{[7,8]}$ They have been preferably used in situations where very thin coverage is required, or when a gliding surface is thought to be necessary to facilitate underlying tissue excursion. ${ }^{[1-5]}$ Purely fascial flaps represent a superior choice when the bulk of a fasciocutaneous or myocutaneous flap hinders movement of the extremity or appears aesthetically unacceptable. Of these, the temporoparietal fascia flap, with its consistent vascular pedicle, is a versatile flap that can be used for a variety of complex reconstructive procedures. ${ }^{[1-5]}$ The flap has a good intrinsic blood supply that can improve local wound conditions for superior healing. The temporoparietal fascia flap was first described in the same year by two authors who were working independently: Brown in 18989 for reconstruction of an ear defect and Monks ${ }^{[10]}$ in 1898 for reconstruction of a lower eyelid defect. Despite this relatively early description, this flap has only become popular as either a pedicled or a microvascular free flap over the past three decades. ${ }^{[1-5]}$ Today, the surgical anatomy and blood supply of the flap are well described, and in clinical practice, it has well-defined indications and is well known for its reliable and versatile properties. ${ }^{[1-6]}$

The temporoparietal fascia flap can be harvested from a region that is inconspicuous and easily concealed by hair; however, it usually requires coverage with a skin graft. This necessitates the creation of another donor site, usually in the thigh, which is hard to conceal. In clinical practice, in all cases to date, the skin graft has been harvested from a site distant from the flap donor site, usually from the thigh. The scalp, which is the donor area for the temporoparietal fascia flap, is a useful donor site for split-thickness skin grafts. ${ }^{[11-14]}$ It has been observed that partial thickness defects of the scalp heal quickly. Re-epithelization depends on proliferation and migration of epidermal elements within the dermis, especially those lining the hair follicles, which are present quite densely in the scalp. This donor area is readily hidden by hair.

In our cases, the temporoparietal fascia flaps were used to reconstruct the soft tissue defects of the distal 
dorsum of the feet and hands, and were then covered with a split-thickness skin graft. The skin grafts were harvested from the same area of the scalp as that from which the flaps were raised. Through this combination of flap and skin graft harvesting from the same side of the scalp, the foot and hand were able to be reconstructed with thin and well-vascularized tissue, and the donor area of both the flap and skin graft was hidden by hair.

Although alopecia is considered the main disadvantage of the temporoparietal fascia flap, this is more common if the vascularity of the overlying skin has already been compromised by trauma, irradiation, infection, or previous surgery. ${ }^{[4,5]}$ If the scalp flaps over the fascia were dissected carefully and directly deep to the hair follicles, the rate of alopecia occurrence is extremely low. When alopecia does occur, however, it is usually transient and resolves within a few months; otherwise, the area can be revised in order to improve the aesthetic outcome. In order to decrease the risk of hematoma formation and subsequent increase in tension on the scalp skin, a suction drain is usually inserted.

Postoperative alopecia, folliculitis, and visible scar formation are potential complications of harvesting skin grafts from the scalp. ${ }^{[11-15]}$ It has been reported that alopecia can occur as a complication of skin graft harvesting from the scalp in 0 to $10 \%$ of the cases. This is mostly related to improper harvesting of the graft. ${ }^{[11,13]}$ The rate of postoperative folliculitis has been reported to be $2 \%,{ }^{[11]}$ and when it occurs, it can be treated with local wound care. The rate of postoperative scar formation is extremely low and is usually due to uneven harvesting of the graft, with some areas being too thick. Repeated harvesting of the skin graft from the scalp is not advised since it can be a cause of an increase in complication rates. ${ }^{[13]}$

The use of saline infiltration in the subgaleal plane provides a good contour and appropriate tension for a simpler and more accurate skin graft harvest. Since the size of the skin graft that is harvested for coverage of the flap is relatively small, excessive bleeding is usually not noted, and there is usually no need to provide special applications such as epinephrine or thrombin solutions to the donor site.

In conclusion, using the same donor area for both the flap and skin graft can provide optimal outcomes at both the recipient and donor sites. This particular region of the body can be easily concealed by hair and is therefore ideal for this combination of tissues. While the reconstruction provided using a thin fascia flap was appropriate for reconstruction of the dorsum of the foot and hand, the patients were also spared an additional donor-site scar.

\section{Acknowledgement}

We thank Akdeniz University Scientific Research Projects Unit for their support of this study.

\section{Financial Disclosure and Products}

None of the authors of this manuscript have any commercial association that might pose or create a conflict of interest with the information presented in the submitted manuscript. This includes: consultancies, stock ownership, or other equity interests, patent licensing arrangements, and payments for conducting or publicizing the study described in the manuscript.

\section{REFERENCES}

1. Smith RA. The free fascial scalp flap. Plast Reconstr Surg 1980;66:204-9.

2. Brent B, Byrd HS. Secondary ear reconstruction with cartilage grafts covered by axial, random, and free flaps of temporoparietal fascia. Plast Reconstr Surg 1983;72:14152.

3. Brent B, Upton J, Acland RD, Shaw WW, Finseth FJ, Rogers C, et al. Experience with the temporoparietal fascial free flap. Plast Reconstr Surg 1985;76:177-88.

4. Hing DN, Buncke HJ, Alpert BS. Use of the temporoparietal free fascial flap in the upper extremity. Plast Reconstr Surg 1988;81:534-44.

5. Woods JM 4th, Shack RB, Hagan KF. Free temporoparietal fascia flap in reconstruction of the lower extremity. Ann Plast Surg 1995;34:501-6.

6. Abul-Hassan HS, von Drasek Ascher G, Acland RD. Surgical anatomy and blood supply of the fascial layers of the temporal region. Plast Reconstr Surg 1986;77:17-28.

7. Chen HC, el-Gammal TA. The lateral arm fascial free flap for resurfacing of the hand and fingers. Plast Reconstr Surg 1997;99:454-9.

8. Meland NB, Weimar R. Microsurgical reconstruction: experience with free fascia flaps. Ann Plast Surg 1991;27:1-8.

9. Brown WJ. Extraordinary case of horse bite: the external ear completely bitten off and successfully replaced. Lancet 1898;1:1533.

10. Monks GH. The restoration of a lower lid by a new method. N Eng J Med 1898;139:385-7.

11. Lesesne CB, Rosenthal R. A review of scalp split-thickness skin grafts and potential complications. Plast Reconstr Surg 1986;77:757-8.

12. Fang K, Stevenson TR. Skin graft from a scalp flap. Plast Reconstr Surg 1987;79:622-4.

13. Martinot V, Mitchell V, Fevrier P, Duhamel A, Pellerin P. Comparative study of split thickness skin grafts taken from the scalp and thigh in children. Burns 1994;20:146-50.

14. Brou J, Vu T, McCauley RL, Herndon DN, Desai MH, Ru$\tan \mathrm{RL}$, et al. The scalp as a donor site: revisited. J Trauma 1990;30:579-81.

15. Chang LY, Yang JY, Chuang SS, Hsiao CW. Use of the scalp as a donor site for large burn wound coverage: review of 150 patients. World J Surg 1998;22:296-300. 